\title{
SEISMIC BEHAVIOUR OF FLAT SLABS IN MULTI-STOREY BUILDINGS NIRANJAN CHAUDHARY ${ }^{1} \&$ NITIN VERMA ${ }^{2}$ \\ ${ }^{I}$ M. E. Scholar, Department of Civil Engineering, Chandīgarh University, Mohali, Punjab, India \\ ${ }^{2}$ Assistant Professor, Department of Civil Engineering, Chandigarh University, Mohali, Punjab, India
}

\begin{abstract}
The growth of population has influenced the construction of multistory buildings day by day. The construction of the building structures with conventional RC slabs are in the public eye since many decades. Although it has more stiffness and minimizes the large moments occurred due to the applied loads, it does not have the advantages in terms of architectural flexibility, easier formwork and shorter construction period compared to the flat slabs. This developing technique of flat slabs construction improves aesthetical and structural aspect of tall building, offices, hospitals, shopping malls etc. As this is considered to be beamless slab, it has less shear strength and less stiffness compared to the conventional slabs. Due to its huge advantages, it is common in both the construction of regular and irregular buildings nowadays. The main motive of the present work is to compare and observe the seismic behavior of $G+13$ storey of regular and different plan irregular buildings (Plus, $T$ and $U$ shape) by using different types of flat slabs (flat plate, drop panel, column head and combination of column head \& drop panel) with the help of E-tabs 17.0.1 software. Later, conventional slab was adopted in the both regular \& irregular models and analyzed in the similar way and compared with flat slab models intended for zone $V$. The nonlinear time history method was carried out to observe the different parameters like storey displacement, storey drift, base shear and time period following the guidelines of IS 1893 (Part 1): 2016.

KEYWORDS: Flat Plate, Drop Panel, Column Head, Nonlinear Time History Analysis, Irregular Building, Storey Displacement
\end{abstract}

Received: Jun 09, 2020; Accepted: Jun 29, 2020; Published: Aug 06, 2020; Paper Id.: IJMPERDJUN2020645

\section{INTRODUCTION}

The construction of buildings using conventional RCC slabs is common since many years. Although it increases the shear capacity and stiffness of the structure; it is being replaced by the developing construction technique (i.e. flat slabs) which was invented by C.A.P. Turner in U.S.A in 1906. These slabs are resting directly on the columns due to which loads are directly transferred to columns. These are considered to be beamless slabs and claim $20 \%$ cost reduction in comparison to conventional RCC slabs. It can be designed and built by both the conventional RCC and post-tensioning. Due to the several advantages like aesthetic appearance, better illumination, flexibility in room layout, shorter construction period, easier formwork, placement of reinforcement has become easier in this type of construction. Since the slab does not have beams, it results in plain ceiling thus providing the aesthetic view from architecture point of view. These types of slabs avoid the beam column clogging due to its speedy and typical type of construction. These are considered to be more flexible than the conventional slabs thus becoming more vulnerable to seismic loading conditions. Generally, two types of failure (i.e. flexure failure and punching shear failure) exists in this type of system. This punching shear is about to occur once the entire shear force goes above the shear resistance of the slab and hence the slab gets pushed down just about the column. This leads to the breakage of the column through the part of the encircled slab and to overcome this type of failure, the additional 
component like drop panel, column head, shear walls, shear reinforcement, bracings etc. are adopted in the structures. Like regular building, these slabs are very common even in irregular buildings. The irregular buildings are considered to be one of the major motives of failure of buildings during earthquake. The irregular buildings are categorized as plan irregularities and vertical irregularities.

\section{Plan Irregular Structures}

It consists of the asymmetrical plan shapes (like T, U, C, O, E etc.) and diaphragms like large openings, cut-outs, re-entrant corners and other sudden changes taking place in diaphragm deformations, stress concentration and torsion.

\section{Vertical Irregular Structures}

When the abrupt changes like stiffness, geometry strength, mass, and geometry exist, it results in distribution of forces and said to be vertical irregular structures.

Though the technique of flat slab construction is new for the south Asian countries, it is very common and popular in developed countries like America, Australia, Norway, Switzerland etc. These are generally used when we need large space inside structures like parking garages, ware house, auditorium, theatres, go-downs, shopping malls, mills, hotels etc.

\section{OBJECTIVES OF THE STUDY}

- To perform the nonlinear time history analysis for all considered regular and plan irregular buildings having flat slabs and conventional slabs as per the guidelines of 1893(Part1):2016 for zone V.

- To check seismic parameters as storey displacement, storey drift, base shear and time period of conventional and flat slabs models for zone $\mathrm{V}$.

- To understand \& study the overall seismic performance of the conventional slab buildings in zone V.

- To compare the seismic behavior of all flat slabs models with conventional slabs models intended for zone V.

- To recognize the most effective \& weak model between the models considered for seismic evaluation for zone V.

\section{MODELING AND ANALYSIS}

Among the several structural elements of the building, the slab is one of the causes of building failure if it is not designed and analyzed accordingly. In this current work, the analysis has been done on the G+13 storey of regular and three types of plan irregular buildings (Plus, U, and T shape) having different sorts of flat slabs (i.e. flat plate, drop panel, column head and column head with drop panel)) with the help of E-tabs 17.0.1 software. Later, conventional slab was adopted in the both regular \& irregular models and analyzed and compared with flat slab models considered for zone V. The Non-linear time history analysis has been adopted for evaluation and observation to know the seismic behavior of the entire considered models in zone V. The considered seismic parameters have been studied and compared carefully with one another to understand the actual behavior of the models during seismic action. Altogether 20 models were analyzed in the present research. The loads like dead load, live load, earthquake load etc. were considered as per Indian standards. The preliminary data of the flat slab buildings are tabulated below. 
Table 1: Preliminary Data for Flat Slab Buildings

\begin{tabular}{|c|l|c|}
\hline S.N & \multicolumn{1}{|c|}{ Particulars } & Dimension/Size/Value \\
\hline 1 & Plan dimension & $30 \mathrm{~m} * 30 \mathrm{~m}$ \\
\hline 2 & No. of stories & $\mathrm{G}+13$ \\
\hline 3 & Floor height & $3 \mathrm{~m}$ \\
\hline 4 & Number of grids in X- dir. & 7 \\
\hline 5 & Number of grids in Y- dir. & 7 \\
\hline 6 & Spacing of grids in X- dir. & $5 \mathrm{~m}$ \\
\hline 7 & Spacing of grids in Y- direction & $5 \mathrm{~m}$ \\
\hline 8 & Size of the column & $600 \mathrm{~mm}($ circular $)$ \\
\hline 9 & Size of beam for conventional building & $450 \mathrm{~mm} * 450 \mathrm{~mm}$ \\
\hline 10 & Slab thickness & $200 \mathrm{~mm}$ \\
\hline 11 & Grade of concrete & $\mathrm{M} 30$ \\
\hline 12 & Grade of steel & $\mathrm{Fe} 415$ \\
\hline 13 & Drop thickness & $280 \mathrm{~mm}$ \\
\hline 14 & Width of drop & $2.5 \mathrm{~m}$ \\
\hline 15 & Column head thickness & $1.25 \mathrm{~m}$ \\
\hline 16 & Width of column strip & $2.5 \mathrm{~m}$ \\
\hline 17 & Live loads & $3 \mathrm{kN} / \mathrm{m} 2$ \\
\hline 18 & Floor loads & $1 \mathrm{kN} / \mathrm{m} 2$ \\
\hline 19 & Roof live & $1.5 \mathrm{kN} / \mathrm{m} 2$ \\
\hline 20 & Zone & V \\
\hline 21 & Soil type & 1.0 \\
\hline 22 & Importance factor & 5 \\
\hline 23 & Response reduction Factor & Type II (medium soil) \\
\hline & & \\
\hline
\end{tabular}

The models considered for the analysis are divided into four cases as follows:

Case 1: Regular building with flat plate, drop panel, column head and combination of drop panel with column head. Altogether 4 models were analyzed in this case.

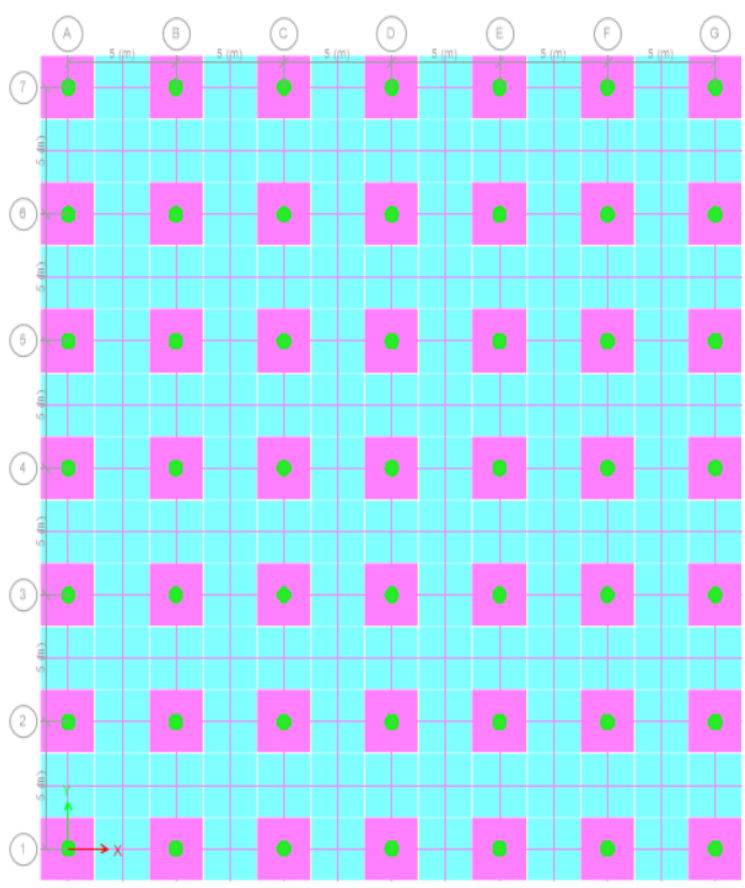

Figure 1: Plan of Regular Shape Building. 
Case 2: Plus (+) shaped irregular building with flat plate, drop panel, column head and combination of drop panel with column head. Altogether 4 models were analyzed in this case.

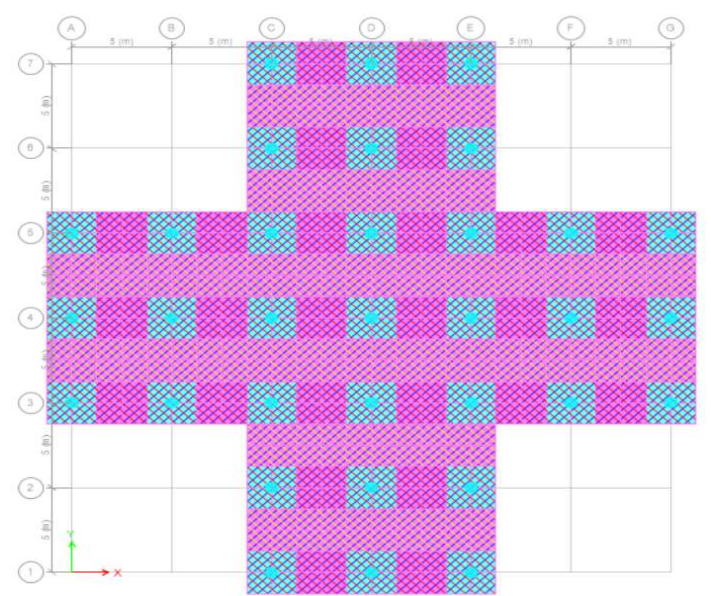

Figure 2: Plan of Plus (+) Shape Building.

Case 3: ' $\mathrm{T}$ ' shaped irregular building with flat plate, drop panel, column head and combination of drop panel with column head. Altogether 4 models were analyzed in this case.

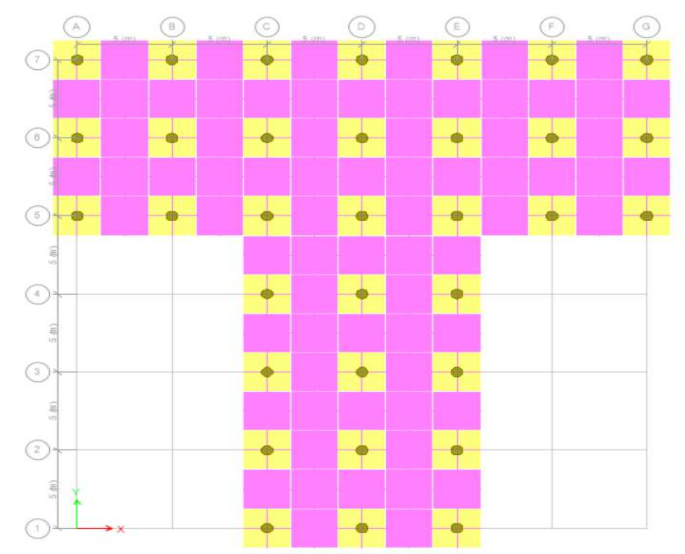

Figure 3: Plan of 'T' Shape Building.

Case 4: 'U' shaped irregular building with flat plate, drop panel, column head and combination of drop panel with column head. Altogether 4 models were analyzed in this case.

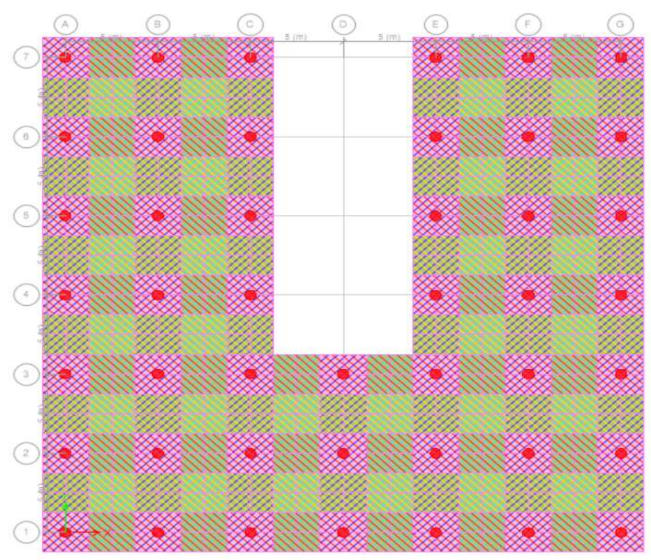

Figure 4: Plan of ' $U$ ' Shape Building. 
Case 5: The all considered regular and plan irregular models (regular shape, plus shape, $\mathrm{U}$ shape and $\mathrm{T}$ shape) having conventional slabs were analyzed. Altogether 4 models were analyzed.

\section{RESULTS AND DISCUSSION}

Non-linear time history analysis was performed for analyzing the flat slabs structures in zone V as per Indian standard code. Based on the seismic parameters like storey displacement, storey drift, storey shear, base shear and time period, the effect of the different components like drop panel, column head, and combination of drop panel \& column head has been observed and tabulated below.

\section{Storey Displacement}

It is total displacement of $\mathrm{i}^{\text {th }}$ storey with respect to ground. It is directly proportional to the height of the structure and also depends on the slenderness of the building structures. The storey displacements of different types of considered models along $\mathrm{X}$ and $\mathrm{Y}$ directions are as follows:

Table 2: Storey Displacement along X-Direction (in mm)

\begin{tabular}{|l|c|c|c|c|}
\hline \multicolumn{1}{|c|}{ Types of Structures } & Regular Shape & Plus Shape & U Shape & T Shape \\
\hline Flat plate Sytem & 103.641 & 96.62 & 98.953 & 101.746 \\
\hline Flat slab with Column head & 94.816 & 87.733 & 90.278 & 92.177 \\
\hline Flat slab with Drop panel & 71.31 & 72.782 & 75.597 & 78.439 \\
\hline Flat slab with Column head having drop panel & 64.307 & 65.485 & 67.775 & 70.607 \\
\hline Conventional building & 54.812 & 54.239 & 58.204 & 58.93 \\
\hline
\end{tabular}

Table 3: Storey Displacement along Y-Direction (in mm)

\begin{tabular}{|l|c|c|c|c|}
\hline \multicolumn{1}{|c|}{ Types of Structures } & Regular Shape & Plus Shape & U Shape & T Shape \\
\hline Flat plate Sytem & 103.641 & 98.368 & 98.512 & 101.603 \\
\hline Flat slab with Column head & 94.816 & 89.355 & 89.81 & 92.445 \\
\hline Flat slab with Drop panel & 71.192 & 72.782 & 69.689 & 72.581 \\
\hline Flat slab with Column head having drop panel & 64.288 & 65.485 & 62.599 & 65.36 \\
\hline Conventional building & 54.812 & 54.239 & 53.944 & 55.385 \\
\hline
\end{tabular}

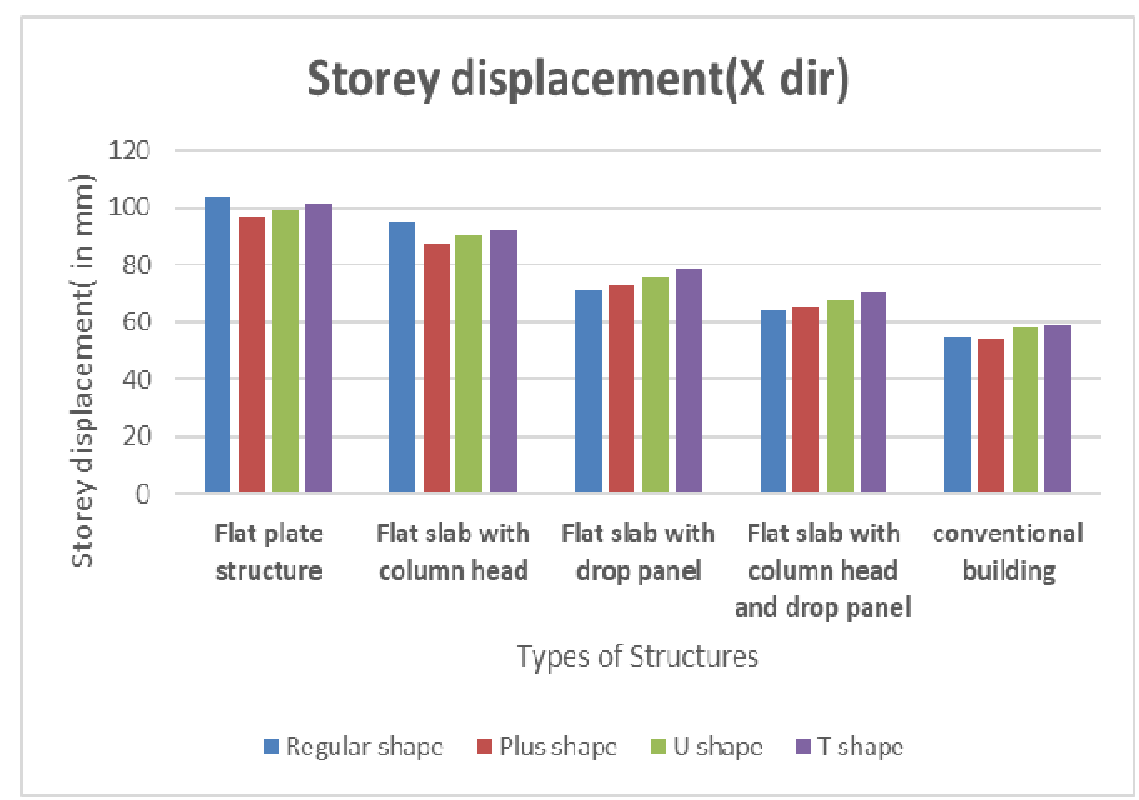

Figure 5: Storey Displacement vs. Types of Structures in X-dir. 


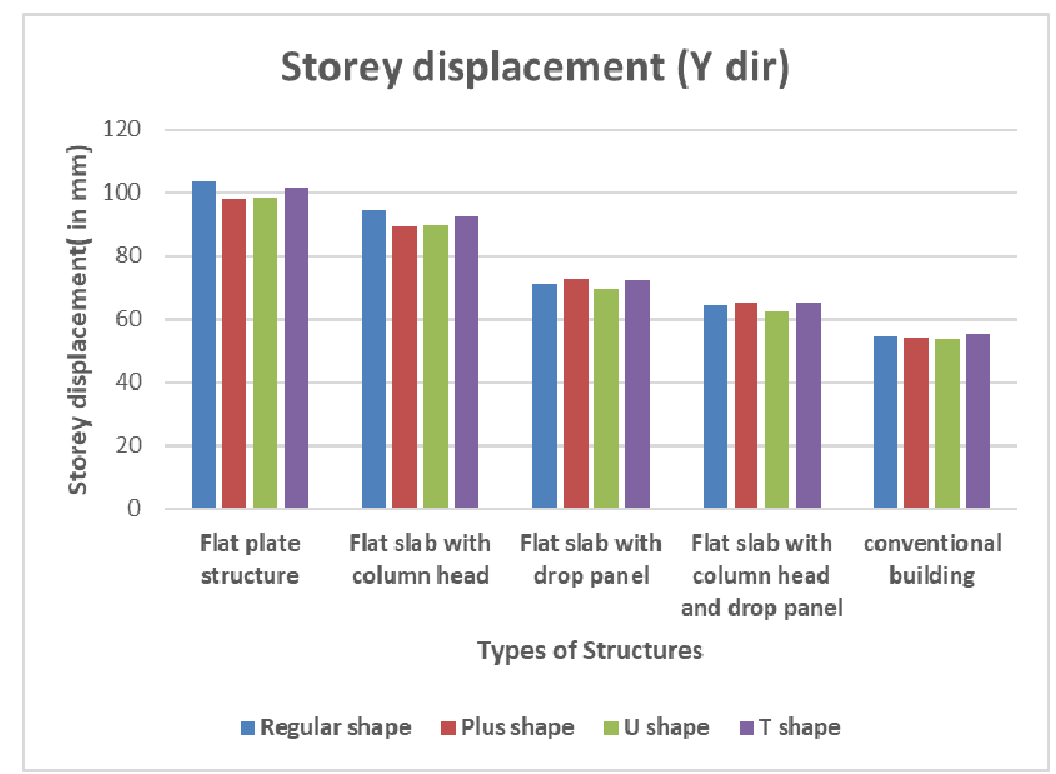

Figure 6: Storey Displacement vs. Types of Structures in Y-dir.

From the above table and graph, it can be easily observed that as the height of the building increases, the storey displacement gets increased. It was seen that the lateral displacement is more in the case of flat plate structure and flat slab with column head. With addition of drop panel, the storey displacement was reduced to a greater extent. Likewise, the combination of flat slab with column head \& drop panel results effectively in reducing the storey displacement in comparison to others.

\section{Storey Drift}

It is defined as ratio of displacement of two consecutive floors to height of that floor. The storey drift in any storey shall not exceed 0.004 times the storey height as per the guidelines of IS 1893 (Part1): 2016. It is very important term used for research purpose in earthquake engineering. The storey drift in all four types of flat slabs buildings and conventional slab buildings along $\mathrm{X}$ and $\mathrm{Y}$ direction are as follows:

\section{- Flat Plate Structures}

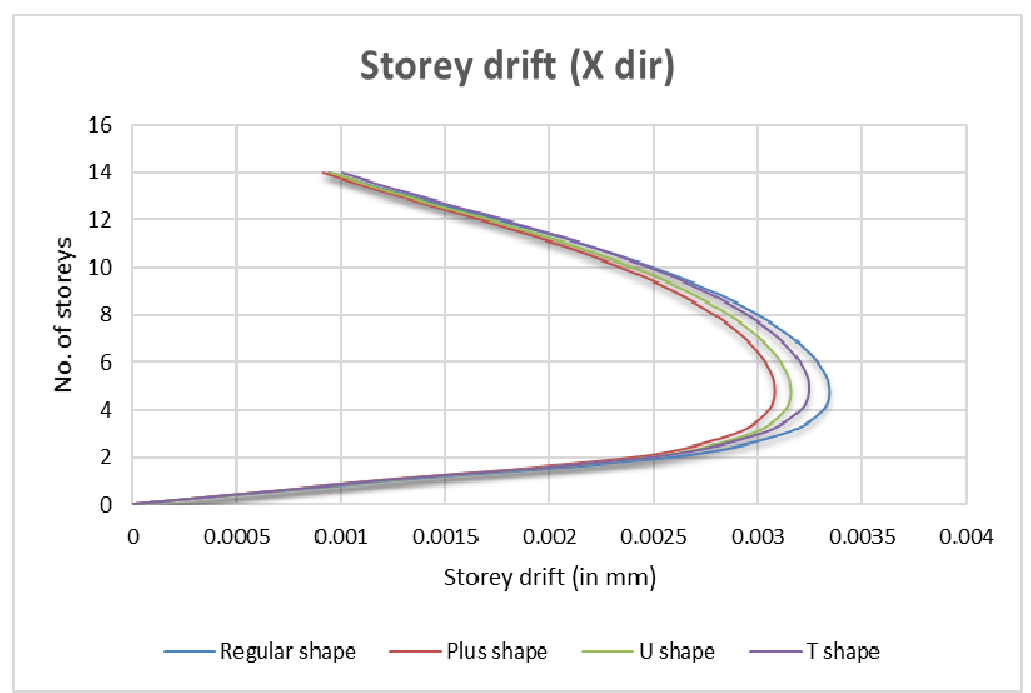

Figure 7: Comparison of Storey Drifts along X-dir. 


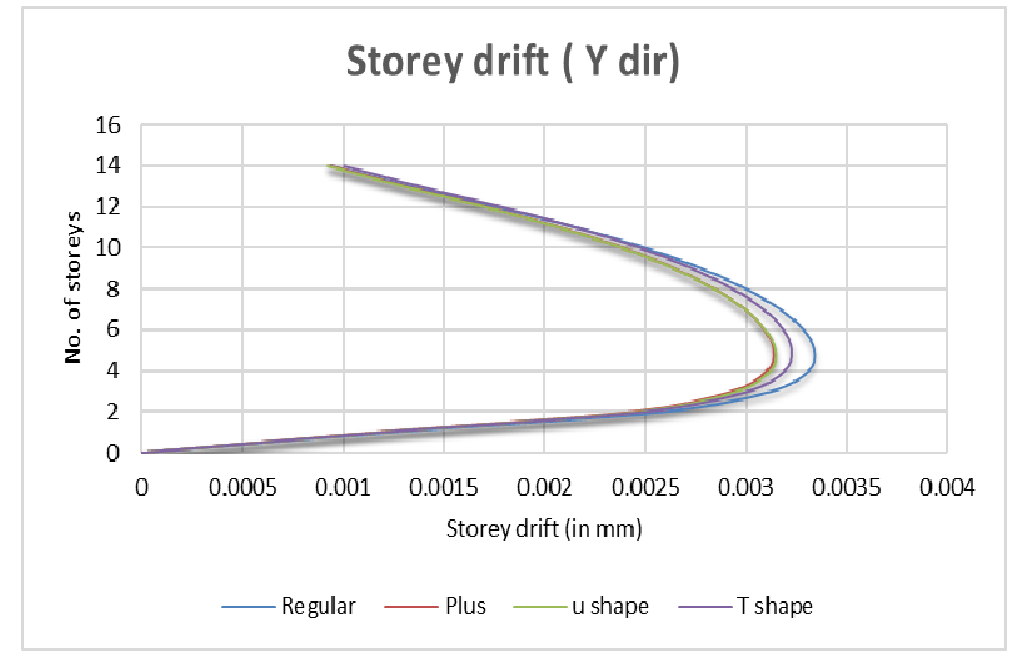

Figure 8: Comparison of Storey Drifts along Y-dir.

- Flat Slab with Column Head Structures

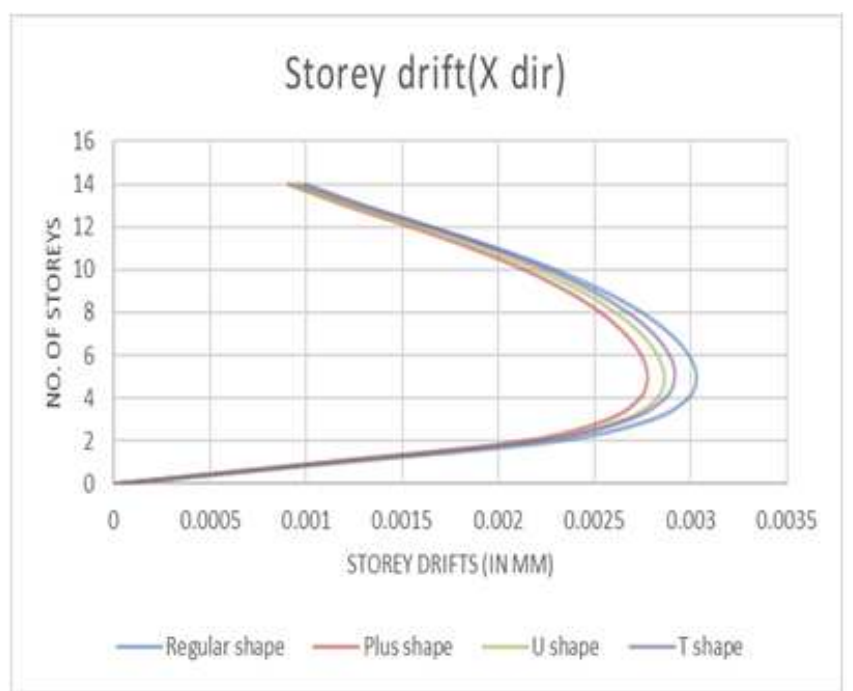

Figure 9: Comparison of Storey Drifts along X-dir.

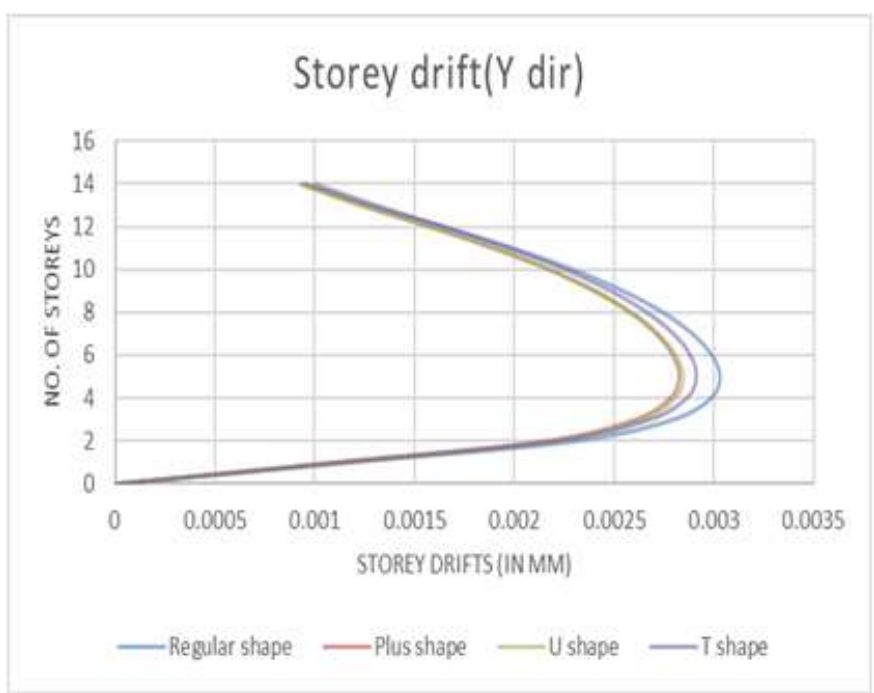

Figure 10: Comparison of Storey Drifts along Y-dir. 
- Flat Slab with Drop Panel Structures

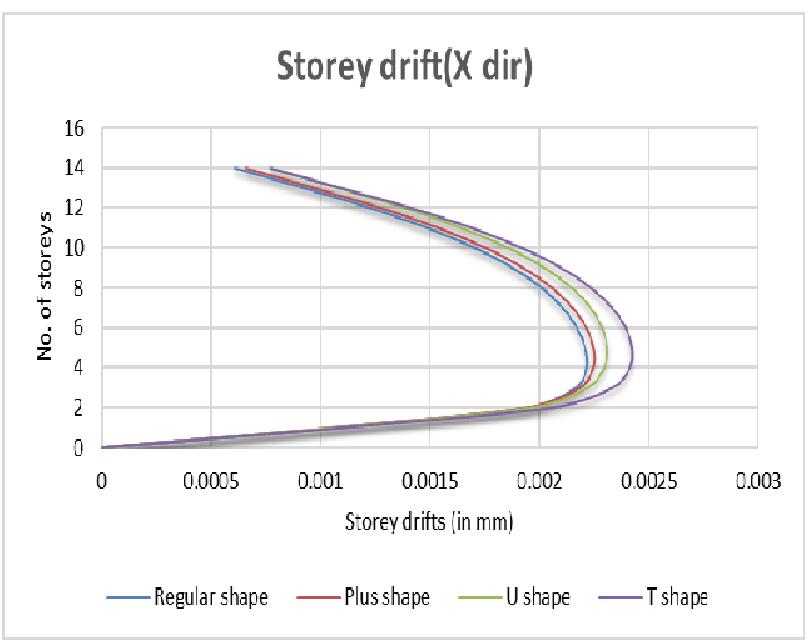

Figure 11: Comparison of Storey Drifts along X-dir.

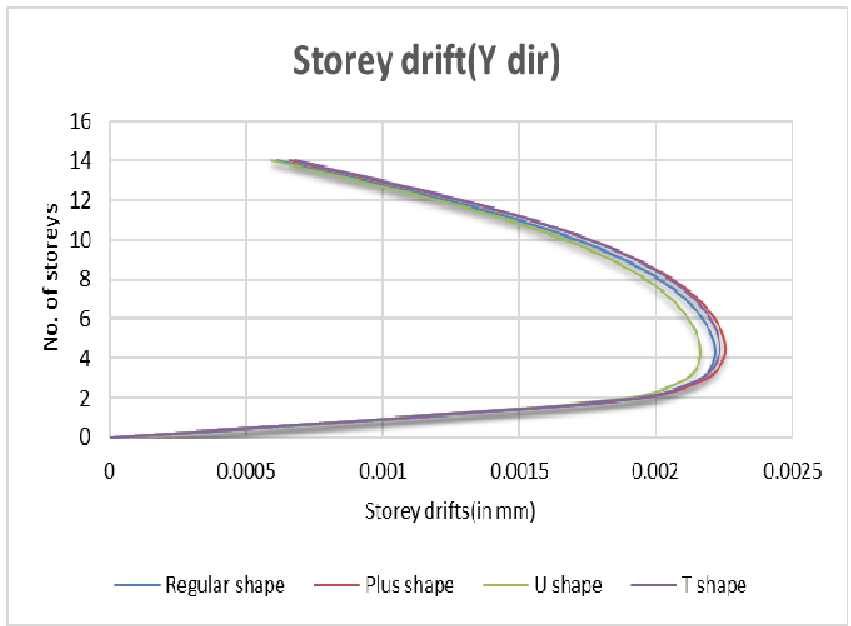

Figure 12: Comparison of Storey Drifts along Y-dir.

- $\quad$ Flat Slab with Drop Panel and Column Head Structures

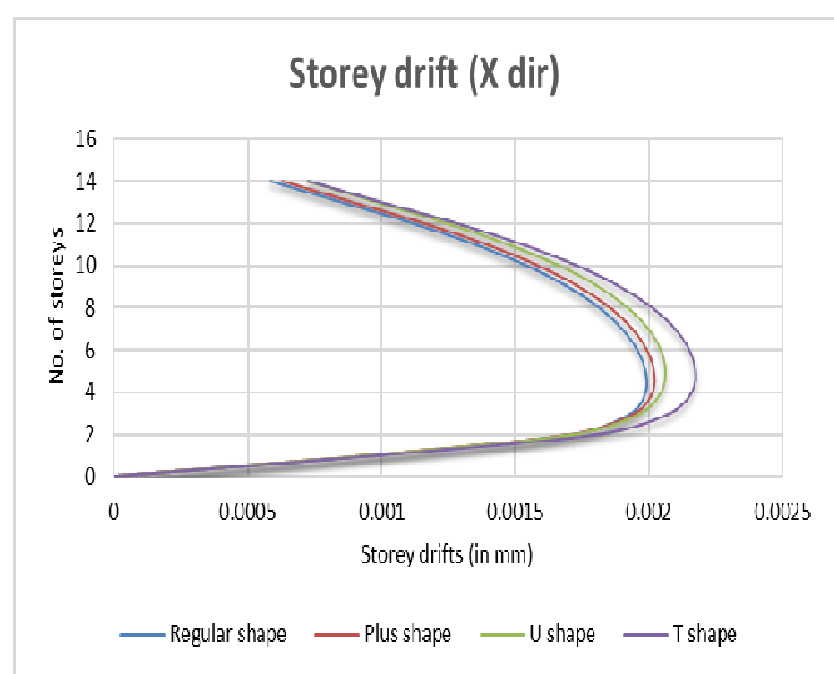

Figure 13: Comparison of Storey Drifts along X-dir. 


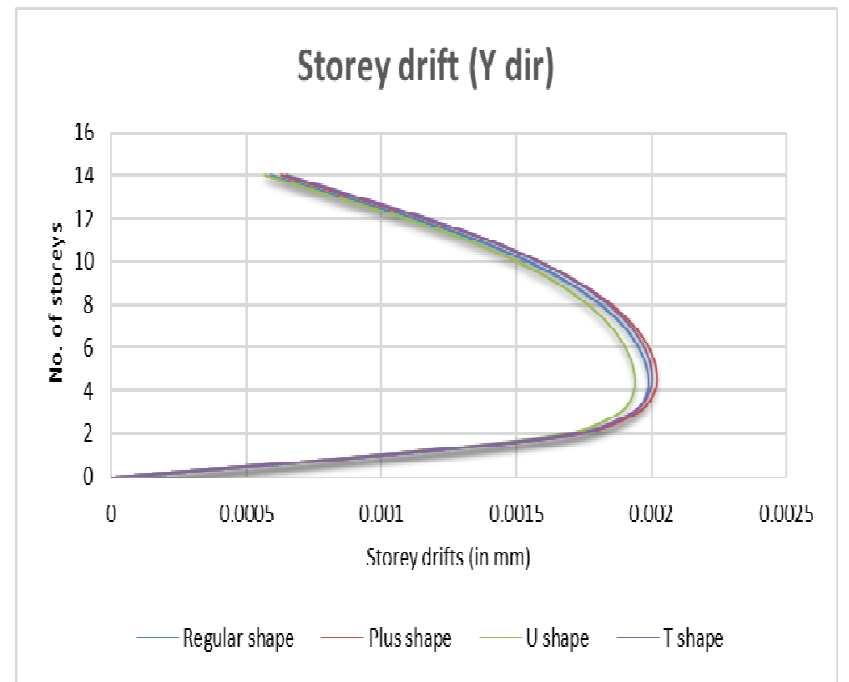

Figure 14: Comparison of Storey Drifts along Y-dir.

From the above graphs, it was seen that the storey drift in all types of flat slabs structures are within the specified limit (i.e. 0.004 times the storey height) as per the guidelines of IS 1893 (Part 1): 2016. The storey drift in flat plate structures was seen more than other types of flat slab structures whereas the combination of flat slab with drop panel and column head seems to have very less storey drift along both $\mathrm{X}$ and $\mathrm{Y}$ direction. The storey drift was found to be more in storey 4 and 5 for all the considered models.

- Storey Drift-Conventional Building

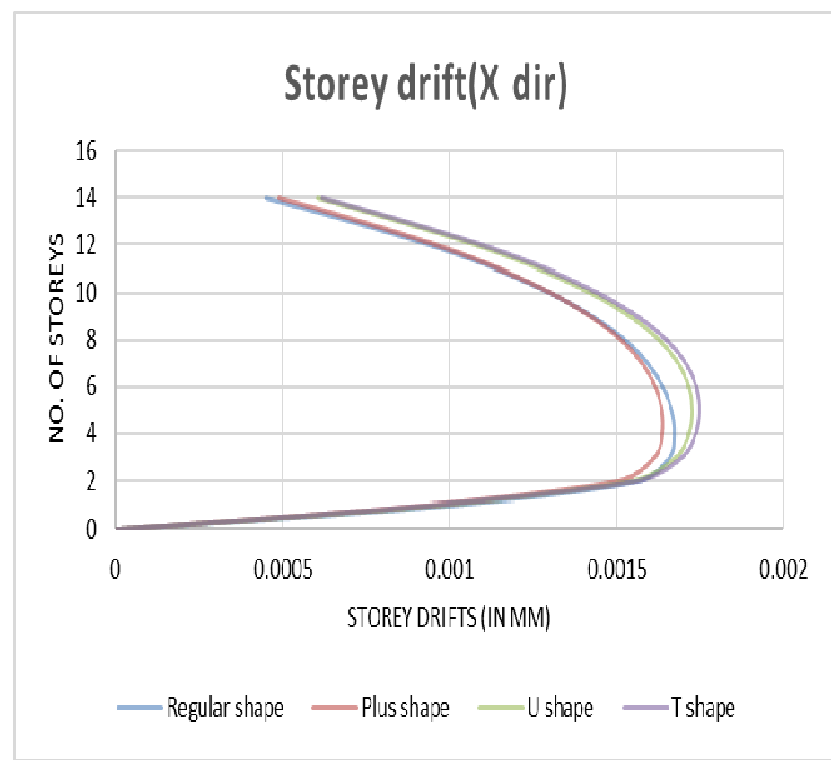

Figure 15: Comparison of Strorey Drifts along X-dir. 


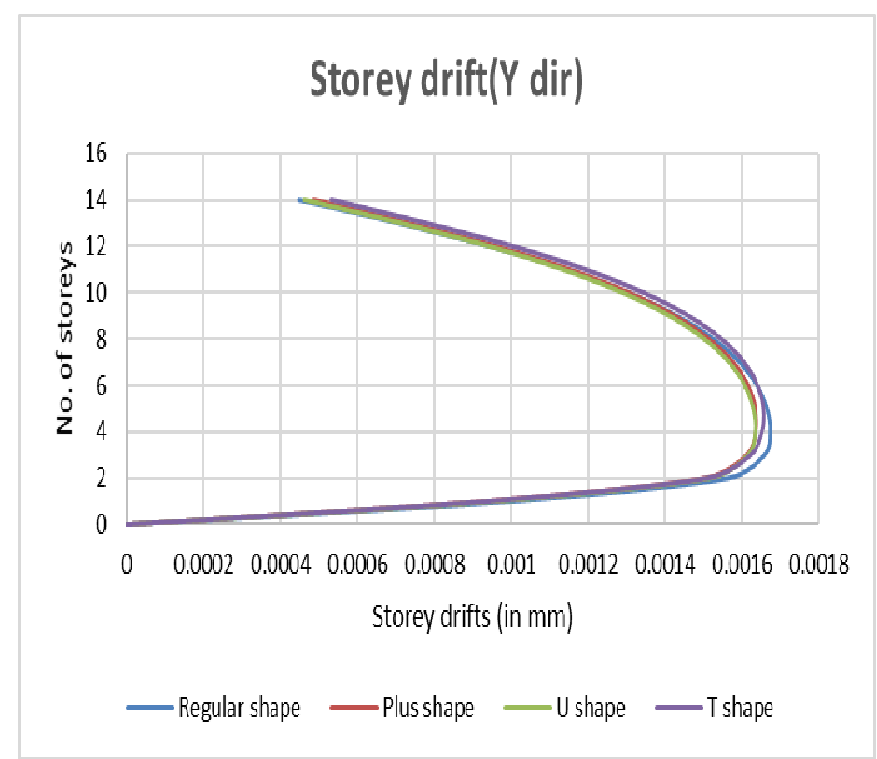

Figure 16: Comparison of Storey Drifts along Y-dir.

As seen above, it is clearly understood that the drift is lesser in both regular and irregular types of buildings. The plus shape has very less storey drift whereas the $\mathrm{T}$ shape has more strorey drift compared to other models. The maximum storey was obtained in storey 4 for regular and plus shape and storey 5 for $U$ and $T$ shaped building. Since the beam slab system reduces the storey drift to a greater extent, it is very much suitable for the zone like $\mathrm{V}$ if one has not to go with flat slab structures.

\section{Base Shear}

It is the total lateral force acting on the building at its base which occurs due to the seismic ground motion.

Table 4: Base Shear along X-Direction (in kN)

\begin{tabular}{|l|c|c|c|c|}
\hline \multicolumn{1}{|c|}{ Types of Structures } & Regular Shape & Plus Shape & U Shape & T Shape \\
\hline Flat plate structure & 2357.411 & 1588.44 & 2260.397 & 1545.407 \\
\hline Flat slab with column head & 2447.868 & 1656.026 & 2350.835 & 1611.096 \\
\hline Flat slab with drop panel & 3737.895 & 2304.963 & 3194.256 & 2298.805 \\
\hline Flat slab with column head and drop panel & 3802.062 & 2306.679 & 3260.892 & 2350.225 \\
\hline Conventional building & 5012.162 & 2980.67 & 3771.203 & 2953.999 \\
\hline
\end{tabular}

Table 5: Base Shear along Y-Direction (in kN)

\begin{tabular}{|l|c|c|c|c|}
\hline \multicolumn{1}{|c|}{ Types of Structures } & Regular Shape & Plus Shape & U Shape & T Shape \\
\hline Flat plate structure & 2357.411 & 1562.192 & 2264.681 & 1544.318 \\
\hline Flat slab with column head & 2447.868 & 1629 & 2356.766 & 1610.719 \\
\hline Flat slab with drop panel & 3743.931 & 2304.963 & 3313.682 & 2342.646 \\
\hline Flat slab with column head and drop panel & 3807.726 & 2360.679 & 3383.905 & 2396.463 \\
\hline Conventional building & 5012.162 & 2980.67 & 4001.795 & 2976.723 \\
\hline
\end{tabular}




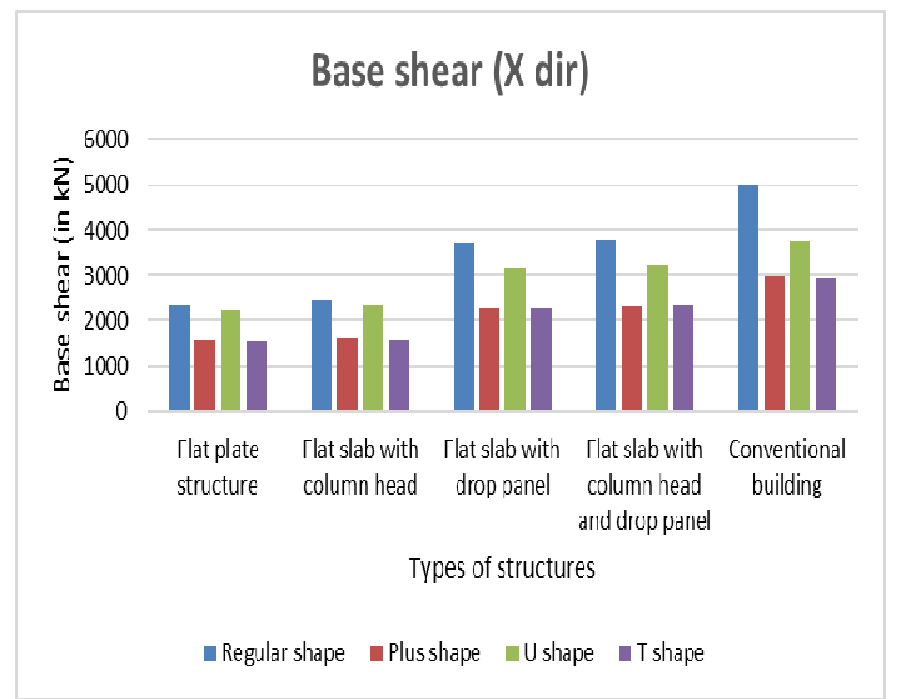

Figure 17: Base Shear vs. Types of Structures in X-dir.

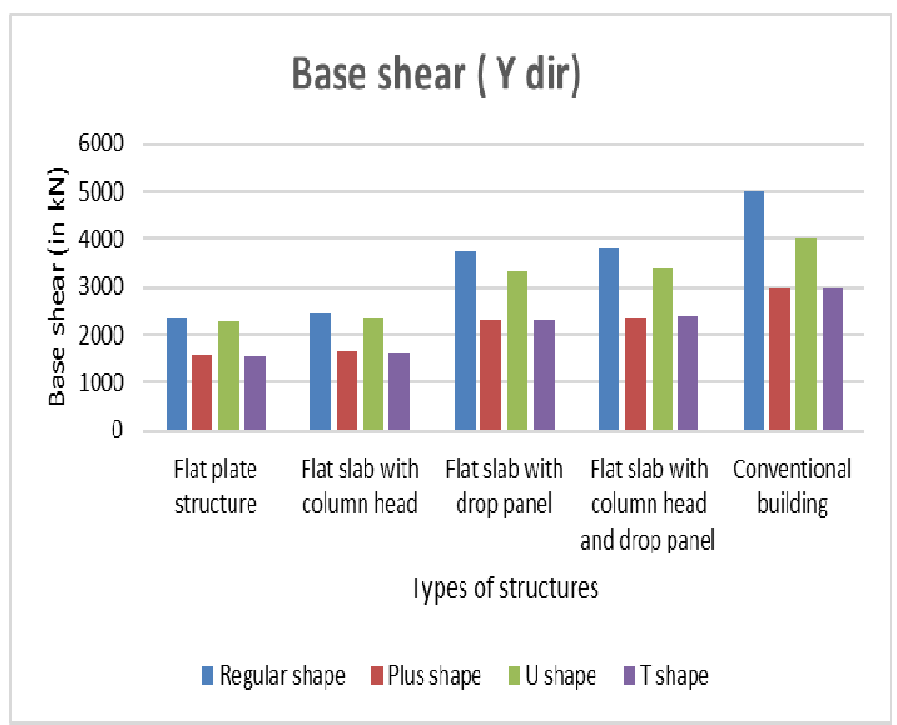

Figure 18: Base Shear vs. Types of Structures in Y-dir.

\section{Time Period}

It is defined as the time taken (in sec) by the structure to complete one cycle of oscillation in its natural mode of oscillation.

Table 6: Time Period (in sec)

\begin{tabular}{|l|c|c|c|c|}
\hline \multicolumn{1}{|c|}{ Types of Structures } & Regular Shape & Plus Shape & U Shape & T Shape \\
\hline Flat plate system & 3.17 & 2.99 & 2.967 & 3.024 \\
\hline Column head System & 2.887 & 2.707 & 2.69 & 2.738 \\
\hline Drop panel System & 2.195 & 2.23 & 2.224 & 2.24 \\
\hline Column head and drop panel System & 1.977 & 2.005 & 1.996 & 2.011 \\
\hline Conventional Building & 1.703 & 1.667 & 1.714 & 1.682 \\
\hline
\end{tabular}




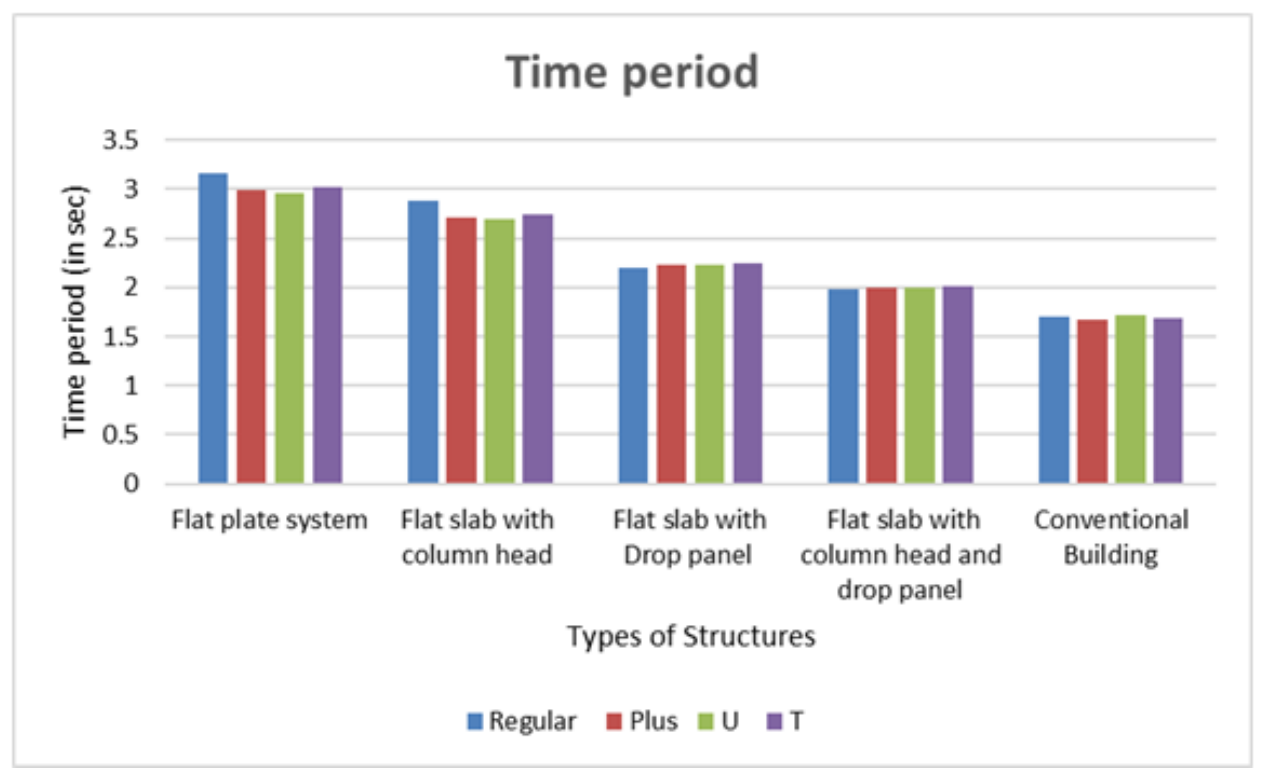

Figure 19: Time Period vs. Types of Structures.

\section{CONCLUSIONS}

From the above results, the various conclusions on the flat slabs have been summarized as follows:

- The lateral displacement of the whole thought models for drop panel system \& drop panel having column head are within limiting value (i.e. h/500) except for flat plate systems and column head systems.

- Since flat plate and column head system go above the limiting value (i.e. h/500), these types of flat slab system should be avoided for construction in zone $\mathrm{V}$.

- Plus shape building with both Flat plate and column head system has very less storey displacement whereas it seems to be slightly decreasing in drop and drop panel with column head \& more heavily in conventional slab system. T shape seems to have more storey displacement even in the drop, column head with drop and conventional building

- Regular shape has more displacement than other models in both flat plate and column head system whereas it goes on decreasing in drop and drop panel with column head system. Likewise, it constitutes very minimum storey displacement in beam slab system compared to flat slab systems.

- In comparison to other models, storey drift for regular shape and plus shape is more \& minimum in flat plate and column head system respectively. The storey drift keeps on decreasing in drop \& column head with drop to a great extent.

- The considered models having beam slab system constitutes very less storey drift compared to flat slab sytems. The regular building has very less storey drift in conventional system whereas $\mathrm{T}$ shape has more storey drift.

- The base shear is more in combination of column head and drop panel than the other three types of flat system. However, the base shear in conventional system is more in comparison to flat slab system. The base shear is more in regular building and less in $\mathrm{T}$ shape in both systems. 
- In flat slab systems, the regular shape was found to be effective in drop panel \& drop with column head system since the time period is very less comparison to other considered models.

- The time period is less in conventional slab system and more in flat plate system. In conventional system, the plus shape has the minimum time period than other models. With addition of drop panel \& column head, the time period goes on decreasing to a great extent.

- Among all, T shape has more time period even in drop \& column head with drop panel system while the regular form shows the less time period in that systems.

From the above results and graphs, it can be concluded that the conventional system is far better for the region like zone $\mathrm{V}$ since it is very severe. If a contractor has to go with the flat slab system, then structure having drop and column head having drop is considered as the safest and effective system. From the overall seismic factors, the plus model was seen more effective in flat plate and column head system though this both practice of construction should be avoided in the region like zone $\mathrm{V}$. The regular building shows good results in drop panel and drop panel with column system whereas the $\mathrm{T}$ shape fails to achieve good seismic performance in both flat systems and conventional systems. Moreover, the models can be added having further external structural elements like shear wall, bracings \& by post-tensioning to diminish the consequences of danger throughout the shaking of the earth. The $\mathrm{U}$ shape and $\mathrm{T}$ shape structure was not seen good option for the zone V by observing the seismic parameters. Out of all these four types of flat slab system, the regular and plus shape was seen performing well appropriate for zone V. The drop \& drop with column head system shows the effective result in flat slab system in reducing the displacement, drift and time period. Overall, the regular structure shows very good seismic behavior than the irregular structures in all aspects in both the flat slab system and conventional system.

\section{REFERENCES}

1. Erberik M.A. and Elnashai S.A., "Fragility analysis of flat slab structures”, ELSEVIER, 2004, pp. 937-948

2. Gupta Uttamasha, Ratnaparkhe and Gome Padma, "Seismic behavior of buildings having flat slabs with drops", International Journal of Emerging Technology and Advance Engineering, Volume 02,2012, pp. 2250-2459

3. K. Navyashree and T. S Sahana, "Use of flat slabs in multistorey commercial building situated in high seismic zone", International Journal of Research in Engineering and Technology, Volume 03, 2014, pp. 2321-7308.

4. Rashied M., "Punching Shear Resistance of Flat Slabs with Opening”, International Journal of Civil Engineering and Technology (IJCIET)", Volume 06, 2015, pp. 0976-6316.

5. Thapa, Axay, and Sajal Sarkar. "Comparative Study of Multi-Storied RCC Building with and without Shear Wall." International Journal of Civil Engineering (IJCE) Vol 6.

6. K. S Muniraju and K. G Subramanya, "Comparative study of seismic analysis between conventional RC frame and flat slab with drop”, International Journal of Science Research and Development, Volume 03, 2015, pp. 2321-0613.

7. S. Ravi and Lekshmi Sreedevi, "Effect of shape and plan configuration on seismic response of structure (zone II and V)", International Journal of Science and Research (IJSR), Volume 05, 2015, pp. 2319-7064.

8. G.B. Muralidhara, K.S. Swathi Rani and Worku Melese, "Seismic Parametric Study on Different Irregular Flat Slab MultiStory Building”, International Journal of Engineering Research \& Technology, Volume 05, 2016, pp. 2278-0181.

9. Surekha, B., M. N. Hegde, and K. S. Jagadish. "Energy and building materials." International Journal of Civil Engineering 5 (2016): 13-24. 
10. G.S. Sandeep and Patil Guraraj, "Comparative study of lateral displacement and storey drift of flat slab and conventional slab structures in different seismic zones”, International Journal of Civil Engineering and Technology (IJCIET), Volume 08, 2017, pp. 567-580.

11. Sahni Bhavesh, Hiwase Prashant D and Dahale Prasad P., "Seismic behavior of flat slab building with shear wall according to I.S.1893 2016”, International Journal of Civil Engineering and Technology (IJCIET), Volume 09, 2018, pp. 955-963.

12. Bayan, Gokul K. "Bi-Layer Footing Foundation System for Multistorey Building-Towards a New Conception and Practices." Research and Development (IJCSEIERD) 3.3 (2013): 59-78.

13. Nayef Sulaiman, Zaki Wael and Rabie Mohamed, "Effect of reinforcement on punching shear behavior of flat slabs", International Journal of Civil Engineering and Technology (IJCIET), Volume 10,2019, pp. 2403-2418.

14. Hasan, Raad Abed Al-Jallal. "Behaviour of beam and wall outrigger in high-rise building and their comparison." International Journal of Civil, Structural, Environmental and Infrastructure Engineering Research and Development 6.1 (2016): 19-30.

15. Duggal S.K., "Earthquake Resistant Design of structures”, Second edition, Oxford University Press, New Delhi, India, 2019.

16. E. Siva Naveen, Abraham N.M. and S.D. Anitha Kumari, "Analysis of Irregular Structures under earthquake loads", ELSEVIER, 2019, pp. 806-819.

\section{AUTHORS PROFILE}

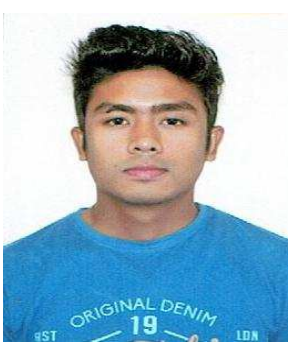

Niranjan Chaudhary Currently pursuing his Master's degree in Structural Engineering from Chandigarh University (CU), Mohali, Punjab India. He received his Bachelor's degree from Visvesvaraya Technological University (VTU), Karnataka, India. His area of research interests are Building construction, Design and Analysis and Earthquake Resistant Structures.

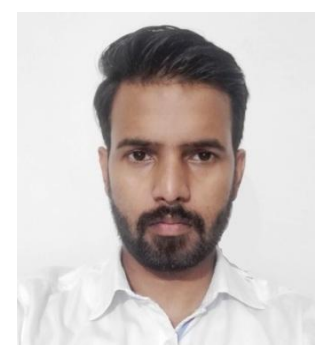

Nitin Verma Assistant Professor, Department of Civil Engineering, Chandigarh University (CU), Mohali, Punjab, India. His area of research interests are Concrete \& Composite Structures, Structural Analysis, High Rise Building and Steel Structures. 